\title{
ORAL HEALTH IN PATIENTS WITH CHRONIC KIDNEY DISEASE
}

\section{AUTHORS}

Radojica Stolic

Faculty of Medicine University of Kragujevac

radojica.stolic@med.pr.ac.rs

Radojica Stolić ${ }^{*}$, Vekoslav Mitrović ${ }^{2}$ Naja Suljković ${ }^{3}$, Dušica V. Miljković-Jakšić ${ }^{4}$, Aleksandra D. Balović ${ }^{4}$, Roksanda N. Krivčević ${ }^{4}$, Sanja M. Jovanović ${ }^{4}$

University of Kragujevac, Serbia, Faculty of Medical Sciences, Department of Internal Medicine, Serbia

${ }^{2}$ University of East Sarajevo, Faculty of medicine Foca, Republika Srpska, Bosnia and Herzegovina

${ }^{3}$ Health center Novi Pazar, Serbia

${ }^{4}$ University of Pristina/Kosovska Mitrovica, Faculty of Medicine, Pristina/K.Mitrovica, Serbia

\section{SUMMARY}

Objective: In the available literature data, there is not much information about problems of patients with end stage kidney disease in relation to oral health. Our objective was to show the importance of oral diseases for patients on hemodialysis.

Data sources: In this review article, the sources of data are review articles and scientific articles in the English language published in MEDLINE database. The choice of studies was based on keywords: Chronic kidney disease, Hemodialysis, Oral health, Periodontal diseases.

Results: It is assumed that almost $90 \%$ patients with chronic kidney disease manifest some symptoms of oral disease. Therefore, it is important to determine the impact of periodontal disease on the progression of kidney failure in these individuals, to evaluate inflammatory parameters in this patient population, to assess the degree of bone loss and periodontal disease index, to determine the presence of bacterial strains, paradontopathy of gingival fluid and antibody titers, to examine correlations of proinflammatory cytokines in the gingival sulcus and serum, as well as to determine the relationship between periodontal tissue and inflammatory mediators. Periodontal diseases can increase the possibility of developing chronic kidney disease by 1.5 to 2 times. These oral diseases include gingival hyperplasia, periodontitis, xerostomia, unpleasant breath, changes in the oral mucosa, malignancies, oral infections, dental abnormalities and bone lesions.

Conclusion: This requires serious cooperation between nephrologists and dentists to make proper communication possible, in order to provide quality dental care for this growing patient population in accordance with new treatment strategies.

Key words: Chronic kidney disease; Hemodialysis; Oral health; Periodontal diseases

\section{SRPSKI}

\section{ORALNE BOLESTI KOD BOLESNIKA SA HRONIČNOM BUBREŽNOM INSUFICIJENCIJOM}

Radojica Stolići“, Vekoslav Mitrović ${ }^{2}$, Naja Suljković ${ }^{3}$, Dušica V. Miljković-Jakšić ${ }^{4}$, Aleksandra D. Balović ${ }^{4}$, Roksanda N. Krivčević ${ }^{4}$, Sanja M. Jovanović ${ }^{4}$

${ }^{1}$ Univerzitet u Kragujevcu, Srbija, Fakultet medicinskih nauka Kragujevac, Katedra Interne medicine, Srbija

${ }^{2}$ Univerzitet u Istočnom Sarajevu, Medicinski fakultet Foča, Republika Srpska, Bosna i Hercegovina

${ }^{3}$ Dom zdravlja Novi Pazar, Srbija

${ }^{4}$ Univerzitet u Prištini/Kosovska Mitrovica, Medicinski fakultet, Priština/K.Mitrovica, Srbija

\section{SAŽETAK}

Cilj: U dostupnim podacima iz literature nema mnogo informacija o problemima pacijenata sa terminalnom fazom bubrežne bolesti u vezi sa oralnim zdravljem. Cilj ovog revijalnog rada je bio da se ukaže na značaj oralnih bolesti za pacijente koji se leče hroničnom hemodijalizom. 
Izvori podataka: U ovom preglednom članku izvori podataka su pregledni i naučni članci na engleskom jeziku objavljeni u MEDLINE bazi podataka. Izbor studija zasnovan je na ključnim rečima: hronična bolest bubrega, hemodijaliza, oralno zdravlje, parodontalne bolesti.

Rezultati: Pretpostavlja se da skoro $90 \%$ pacijenata sa hroničnom bolešću bubrega imaju neke simptome koji ukazuju na oralne bolesti. Zbog toga je važno utvrditi uticaj parodontalne bolesti na napredovanje bubrežne insuficijencije kod ovih osoba, proceniti inflamatorne parametre u ovoj populaciji pacijenata, proceniti stepen gubitka kostiju i indeks parodontalne bolesti, utvrditi prisustvo bakterijskih sojeva, da se ispita korelacija proinflamatornih citokina u gingivalnom sulkusu i serumu, kao i da se utvrdi odnos između parodontalnog tkiva i medijatora zapaljenja. Parodontalne bolesti mogu povećati mogućnost razvoja hronične bolesti bubrega 1,5 do 2 puta. Oralne bolesti uključuju hiperplaziju desni, parodontitis, kserostomiju, neprijatan dah, promene na oralnoj sluznici, maligne bolesti, oralne infekcije, zubne abnormalnosti i lezije kostiju.

Zaključak: Oralne bolesti kod bolesnika sa hroničnom bubrežnom insuficijencijom zahtevaju ozbiljnu saradnju nefrologa $i$ stomatologa kako bi se omogućila odgovarajuća komunikacija i kako bi se ovoj rastućoj populaciji pacijenata pružila kvalitetna stomatološka nega u skladu sa najnovijim strategijama lečenja.

Ključne reči: Hronična bubrežna insuficijencija, Hemodijaliza, Oralne bolesti, Parodontalne bolesti

\section{INTRODUCTION}

\section{Actuality of research}

Current guidelines in nephrology do not deal with specific problems of oral health in patients with chronic kidney diseases [1]. However, there are several aspects that indirectly affect these problems. In line with the latest evidence of good clinical practice concerning medical and dental referrals for patients on hemodialysis, it will surely become imperative to establish interdisciplinary communication.

During recent years the prevalence of patients with chronic kidney diseases has noticeably increased. For example $14 \%$ of the adult population in the United States of America are estimated to suffer from chronic kidney diseases with significant financial costs. In 2008, more than $\$ 30$ billion was spent on their treatment. Patients with moderate kidney diseases were found to have 2-3 times higher mortality than the general population. Namely, chronic kidney diseases is the ninth leading cause of death in the United States of America [2,3].

Almost all chronic diseases are associated with poor oral health, which leads to a need for better dental care. This is particularly evident in patients with chronic kidney diseases, where oral diseases are a potential cause of worsening of their already fragile health. In the global health system dental disease and periodontitis are considered to be among the most expensive conditions to treat [3].

Existing data on the prevalence and severity of oral disease in patients with chronic kidney diseases are limited to a few studies with small samples. They show different incidences of oral disease in such patients. However, based on these meager data it is estimated that nearly $90 \%$ of patients with chronic kidney diseases exhibit some symptoms of oral disease, especially gingival enlargement, xerostomia and changes in the flow and composition of saliva [4]

Patients with chronic kidney diseases require special attention in relation to dental services, not only due to conditions typical of this disease, but also because of the multiple oral manifestations, side effects and specificities of therapeutic treatment [4]. The medical, psychological and socio-economic characteristics of individuals with end stage kidney diseases potentially affect oral health problems and contribute not only to quality of life, but also to morbidity and mortality. Up to now, serious studies have documented a link between cardiovascular disease on the one hand, and periodontal disease and gum infections on the other. Current research indicates a correlation between gum infections and kidney disease. Periodontitis is an inflammatory response to persistent infection caused by bacteria penetrating into the porous gum tissue, and this inflammatory condition can affect major organs, including the kidneys [5].

\section{Search Strategy}

In the present article review, scientific articles in the English language published in MEDLINE database.

We used keywords to search the database: Chronic kidney disease, Hemodialysis, Oral health, Periodontal diseases.

\section{Gingival hyperplasia}

Gingival hyperplasia, usually a result of drug side effects, is one of the most widely documented oral manifestations in patients with kidney disease. There can also be a so-called additive effect, when hyperplasia mainly affects the labial surface of the interdental papilla [6].

Most epidemiological studies have established paleness of the gingiva (due to the anemia of chronic disease), petechiae and ecchymosis, resulting from anticoagulation therapy and/or platelet dysfunction. Periodontal problems creating large dents and deep pockets often occur in patients with chronic kidney diseases because of these predisposing factors. The prevalence of periodontal disease in this population of patients is increased most likely by immune suppression in uremia. This inhibits the inflammatory response of gingiva to plaque accumulation [5].

Chronic kidney disease and paradontopathy also connect common risk factors, such as diabetes mellitus, [7] age and tobacco smoking [8]. It is believed that periodontal conditions are a non-traditional risk factor for chronic kidney diseases, due to systemic changes caused by periodontal inflammation. Due to the parodontogenic presence of bacteria, inflammatory mediators like interleukin-1, interleukin-6, prostaglandine 2 and tumor necrosis factor alfa are locally produced and their antigens may reach the circulation [9]. Recent studies have shown that, in comparison with healthy people, patients with periodontitis may have elevated levels of C-reactive protein and, consequently, a mild systemic acute phase inflammatory response. Since the connection between chronic systemic infection and chronic kidney diseases, as measured by levels of C-reactive protein, has been long known, periodontitis as a source of "chronic inflammation", may contribute to worsening of the chronic kidney diseases [10]. 


\section{Xerostomia}

Xerostomia arises as a result of restricting fluid intake, unwanted effects of drugs (antihypertensives), subsequent to possible lesions of the salivary glands, decreased production of saliva and damage to peripheral airways. Frequent chronic infections of the salivary glands are manifested by raised levels of proinflammatory cytokines in saliva. However, the effect of this increase on oral manifestations has not been extensively studied. Salivary enzymes require an alkaline environment in the oral cavity. The buffering capacity of saliva was found to be significantly reduced in patients with chronic kidney diseases [11, 12].

\section{Bad breath and taste in mouth}

Patients complain of the sense of an unpleasant odor and metallic taste in the mouth. This is partly due to increased concentrations of salivary urea and its transformation into ammonia [13].

\section{Changes on the oral mucosa}

Uremic stomatitis includes lupus, ulcerative and hemorrhagic-hyperkeratotic forms. These lesions are very painful and usually occur on the ventral surface of the tongue, as well as on the front of the mucosal surface, and they are very resistant to treatment but may disappear after 2-3 weeks of intensive dialysis treatment. Mucosal lesions (white plaques and/or ulcerations) appear frequently. Customary findings are lichenoid lesions that are associated with certain drugs and/or oral leukoplakia, as a secondary manifestation of therapy-induced immune suppression. Stomatitis and xerostomia are prevalent among dialysis patients. Stomatitis is characterized by carmine red mucous membranes, while xerostomia arises after rigorous restrictions on liquids and side effects of medicaments. Inadequate treatment of stomatitis and xerostomia can lead to malnutrition because of the impossibility of adequate food intake. In patients on hemodialysis vitamin and mineral deficiencies may occur due to poor appetite, depression, gastrointestinal tract disorders, difficulty in swallowing and dietary restrictions. Vitamin and mineral imbalance can be identified, e.g. lack of vitamin E may cause aphthous stomatitis, but each deficit can be compensated by adequate substitution after completion of dialysis treatment [14-16].

\section{Malignity}

The most common form of malignancy after kidney transplantation arises due to epithelial dysplasia and cancer of the lips. The increased risk of malignancy in patients with chronic kidney diseases is most likely caused by iatrogenic immunodeficiency, which enhances sensitivity to the mucous-tumor virus, as observed in patients with Kaposi's syndrome and non-Hodgkin's disease [17, 18].

\section{Oral infection}

Infections, especially candidiasis, are almost a customary finding in patients after kidney transplantation and those on dialysis. Thus, cytomegalovirus infection is common in the first few months after receiving a kidney. Moreover, immunosuppression increases sensitivity to human herpesvirus. Oral infections may lead to increased levels of $\mathrm{C}$-reactive protein, thus raising the incidence of cardiovascular disease [19].

\section{Dental anomalies}

Hyperplasia of enamel, due to changes in the metabolism of calcium and phosphorus, can affect both primary and permanent teeth. Its severity depends on the age of patients, the duration of kidney disease and the type of dialysis treatment. Serious erosion of the gingival surface of the teeth may also be observed after frequent vomiting, medication and/or dialysis. Obliteration of the pulp may result from imbalances of calcium and phosphorus metabolism. Loose teeth, malocclusion, calcification of the pulp and temporomandibular joint may also occur. It is interesting that there is a lower prevalence of dental caries. This is attributed to the protective effect of urea, which inhibits bacterial growth and neutralizes bacterial plaques and/or changes the $\mathrm{pH}$ of the oral cavity. Changes in dental tissues include: late eruption of teeth, enamel hypoplasia, loss of lamina dura, extension of the periodontal ligament, periodontal destruction, mobility of teeth, dental pulp calcification and narrowing of the pulp chamber [16].

\section{Changes in bone}

In patients with chronic kidney diseases mechanisms for physiological regulation of calcium and phosphorus, vitamin $D$, parathyroid hormone and fibroblast growth factors are marred, which affects the integrity of bone structure leading to renal osteodystrophy. It was found that only $2 \%$ of hemodialysis patients have normal values after histomorphometric analysis of bone biopsies. Animal studies indicate a decrease in cortical thickness of the mandible in a mouse model. Changes in bone include: demineralization of the jaw bone, less trabeculation, reduced thickness of cortical bone, metastatic calcification in soft tissues, fibrocystic radiolucent bone lesions, bone fractures and disordered healing after tooth extraction [20-22].

\section{The effect of kidney disease on periodontal tissue}

The specific effects of kidney disease and kidney replacement therapy on periodontal tissues, include gingival hyperplasia, especially in patients receiving immunosuppressive therapy after kidney transplantation, together with a high level of plaque, calculus, gingival inflammation and increased destruction of the periodontium. Gingival hyperplasia that occurs due to long-term therapy with calcineurin inhibitors and calcium channel blockers, is the most common complication in dialysis patients. Magnification gingiva may be so pronounced that it is often indicated for surgical therapy. Recent studies have shown that the prevalence of cyclosporine-induced gingival hyperplasia in patients with transplants varies between 22 and 58\%. Moreover, the addition of a calcium channel blocker, particularly nifedipine, in patients receiving cyclosporine and tacrolimus may raise the frequency and severity of gingival hyperplasia [23-24]. The mechanism of calcineurin inhibitor-induced gingival hyperplasia is not known. However, recent studies have shown that genetic factors are associated with polymorphism of the transforming growth factor beta 1 gene [25].

Studies that focus on the periodontal health of dialysis patients, indicate poor oral hygiene and gingivitis, together with an increased level of dental plaque, calculus and consecutive infections of the gingiva [16, 26-31]. This is probably a consequence of the strong uremic syndrome, associated with impaired immune function, as well as altered activity of lymphocytes and monocytes [32]. Many authors have found that the longer is dialysis depuration, the worse is the state 
of oral health, and this contributes significantly to the num-ber of comorbidities, particularly diabetes mellitus [33].

Periodontitis is associated with elevated values of other components of the acute phase of inflammation, including lower concentrations of high density lipoproteins [34, 35], increased amounts of low density lipoproteins [36-38] and neutrophils [39]. It is important to note that treatment of pe-riodontal disease can be followed by reduced levels of C-rea-ctive protein [40].

Since diseased periodontal tissue is exposed to chronic inflammation, it is likely that oral bacteria can affect the co-urse of chronic kidney diseases. Greater numbers of perio-dontal red complex bacteria ( $\mathrm{P}$. gingivalis, T. forsythia, T. denticola) and C. albicans, as well as significant destruction of periodontal tissue have been found in patients with chro-nic kidney diseases [41] as well as more periodontal bacteria (P. gingivalis, $\mathrm{T}$. forsythia, P. intermedia and P. nigrescens, A. actonomycemconcomitans) in periodontal pockets in these patients [42]. Dialysis patients with severe periodontitis have increased concentrations of proinflammatory cytokines (interleukin-8, tumor necrosis-alfa) and $\mathrm{C}$-reactive protein in the gingival fluid and serum. However, classic nonsurgical treatment of periodontitis can reduce the levels of markers of inflammation [43].

Therefore, regular evaluation and prevention of perio-dontitis is of particular importance in patients with chronic kidney diseases. During periodontitis levels of some pro-inflammatory cytokines (interleukin-1B, interleukin-6, tu-mor necrosis-alfa) increase [39], thereby stimulating the immune system. This modifies the metabolism of fats and enhances production of C-reactive protein, which leads to endothelial dysfunction, atherosclerosis, ischemic heart di-sease and glomerulonephritis [40]. It is therefore not surpri-sing that numerous studies have established a connection be-tween chronic kidney diseases and periodontal disease [44-47] in patients with end stage kidney disease, most likely due to an altered immune response.

\section{Prevention of oral disease}

Prevention of oral disease in patients with chronic kidney diseases involves the application of a series of necessary measures (Table 1) [48].

Table 1. Oral diseases prevention measures

in patients with chronic kidney diseases
Table 2. Dental care measures and procedures in hemodialysis patients

Consultation with the dentist to provide information about the state of the kidney disease, the type of therapeutic treatment, the best timing for dental intervention and the most significant medical complications that can arise. Any modification of therapy, or any aspect of dental treatment should be previously agreed with the nephrologist.

-Interdisciplinary cooperation between nephrologists and dentists will improve the oral and general health of patients with chronic kidney diseases.

-Before any invasive dental procedure, it is necessary to obtain a whole set of laboratory analyses, particularly blood counts and coagulation tests.

-Prior elimination of any oral infection with antibiotic prophylaxis, especially if there is risk of bleeding or sepsis after tooth extraction, treatment of periodontal endodontics and periapical surgery, in orthodontic procedures for prostheses, as well as surgical implants and reimplants, etc.

-It is necessary to control blood pressure before and during dental treatment, as well as to use sedatives for patients with an expressed anxiety disorder.

-Due to altered metabolism and elimination of certain drugs, it may be necessary to adjust and modify the dose and frequency of intake.

- In hemodialysis patients it is recommended that dental treatment is carried out on days when patients are not on hemodialysis because of the increased risk of bleeding due to heparinization during the procedure. Heparin has an elimination half-life of 4-6 hours. In any case, before any dental intervention, apart from a complete blood count, it is necessary to determine coagulation parameters, and provide mechanical compression, surgical strings, thrombin, microfibrillar collagen and oxidant regenerated cellulose. Application of desmopressin is reserved for the control of severe bleeding, and conjugated estrogens can be used to establish long-term hemostasis. Although there are conflicting opinions on the preventive application of antibiotics, a $2 \mathrm{~g}$ dose of amoxicillin per os, one hour before the dental procedure is recommended to prevent bacterial endocarditis.

Due to frequent transfusions, dialysis patients are at increased risk of infection with hepatitis $\mathrm{B}$ and $\mathrm{C}$ viruses, Human immunodeficiency virus infection and tuberculosis, which are of exceptional epidemiological significance.

- In the pretransplantation procedure dental evaluation is very important, in order to eliminate existing focal infections, also all teeth with an uncertain prognosis should be removed.

-In patients who receive chronic corticosteroid therapy additional intravenous hydrocortisone (25 $\mathrm{mg}$ ) is required before the intervention to prevent a cortisone crisis.

- Owing to impaired glucose control and high blood pressure in many patients with chronic kidney diseases it is desirable to minimize stress and carry out all interventions painlessly.

-Lidocaine is a safe local anesthetic for use in dental practice.

\begin{tabular}{|c|c|}
\hline $\begin{array}{l}\text { Table 1. Oral diseases prevention measures } \\
\text { in patients with chronic kidney diseases }\end{array}$ & of this artic \\
\hline \multicolumn{2}{|l|}{-A balanced diet } \\
\hline \multicolumn{2}{|l|}{-Avoidance of carbohydrates } \\
\hline \multicolumn{2}{|l|}{-Use of fluoridated water } \\
\hline \multicolumn{2}{|l|}{-Avoidance of alcohol and tobacco } \\
\hline \multicolumn{2}{|l|}{ - Use of a soft-bristled toothbrush and dental floss } \\
\hline \multicolumn{2}{|l|}{ - Toothbrushes must not be shared with others and be changed every 3 months } \\
\hline \multicolumn{2}{|l|}{ - Regular tooth brushing at least $2 \mathrm{x}$ a day with fluoridated toothpaste } \\
\hline \multicolumn{2}{|l|}{-Use of dental floss every day } \\
\hline -Wash hands before and after using dental floss & \\
\hline - Regular dental and oral health checks at 6 month intervals & \\
\hline
\end{tabular}

\section{CONCLUSION}

It is necessary to point out that a nephrologist should be included in the process of providing dental services, and the implementation of adequate measures and procedures in the dental care of hemodialysis patients (Table 2) [48].

Comprehensive review of this problem, in patients with terminal renal insufficiency, requires serious cooperation between nephrologists and dentists to make proper communication possible, in order to provide quality dental care for this growing patient population in accordance with new treatment strategies.

\section{CONFLICT OF INTEREST}

The authors declare no potential conflicts of interest with respect to the research, authorship, and/or publication

列




\section{LITERATURA}

1. National Kidney Foundation: KDOQI Clinical Practice Guideline for Diabetes and CKD: 2012 update. Am J Kidney Dis. 2012; 60: 850-6.

2. Strippoli G.F., Palmer S.C., Ruospo M., Natale P., Saglimbene V., Craig J.C., et al ORAL-D Investigators: Oral disease in adults treated with hemodialysis: prevalence, predictors, and association with mortality and adverse cardiovascular events: the rationale and design of the ORAL Diseases in hemodialysis (ORAL-D) study, a prospective, multinational, longitudinal, observational, cohort study. BMC Nephrol. 2013; 19 (14): 90.

3. Grubbs V., Plantiga L.C., Tuot D.S., Powe N.R.: Chronic kidney disease and use of dental services in a United States public healthcare system: a retrospective cohort sudy. BMC Nephrol. 2012; 13: 16.

4. Araújo M.V., Hong B.Y., Fava P.L., Khan S., Burleson J.A., Fares G., et al: End stage renal disease as a modifier of the periodontal microbiome. BMC Nephrol. 2015; 16:80. doi: 10.1186/s12882-015-0081-x.

5. Ausavarungnirun R., Wisetsin S., Rongkiettechakorn N., Chaichalermsak S., Udompol U., Rattanasompattikul M.: Association of dental and periodontal disease with chronic kidney disease in patients of a single, tertiary care centre in Thailand. BMJ Open. 2016;6:e011836. doi: 10.1136/bmjopen-2016-011836.

6. Dioguardi M., Caloro G.A., Troiano G., Giannatempo G., Laino L., Petruzzi M., et al: Oral manifestations in chronic uremia patients. Ren Fail. 2016;38(1): 1-6.

7. Simpson T.C., Needleman I., Wild S.H., Moles D.R., Mills E.J.: Treatment of periodontal disease for glycaemic control in people with diabetes. Cochrane Database Syst Rev. 2010; 12 (5): CD004714.

8. Chambrone L., Chambrone D., Pustiglioni F.E., Chambrone L.A., Lima L.A.: The influence of tobacco smoking on the outcomes achieved by root-coverage procedures. A systematic review. J Am Dental Assoc. 2009; 140: 294-6.

9. Kshirsagar A.V., Offenbacher S., Moss K.L., Barros S.P., Beck J.D.: Antibodies to periodontal organisms are associated with decreased kidney function. The Dental Atherosclerosis Risk In Communities study. Blood Purif. 2007; 25: 125-2.

10. Paraskevas S., Huizinga J.D., Loos B.G.: A systematic review and meta-analyses on C-reactive protein in relation to periodontitis. J Clin Periodontol. 2008; 35: 277-90.

11. Hernández C.: Oral disorders in patients with chronic renal failure. Narrative review. J Oral Res. 2016; 5(1): 27-4

12. Soroye M.O., Ayanbadejo P.O.: Oral condition, peridontal status and peridontal treatment need of chronic kidney disease patients. J Oral Res Rev. 2016; 8: 53-8.

13. Anuradha B.R., Katta S., Kode V.S., Praveena C., Sathe N., Sandeep N., et al: Oral and salivary changes in patients with chronic kidney disease: A clinical and biochemical study: J Indian Soc Periodontal. 2015; 19: 297-3.

14. Kaushik A., Reddy S.S., Umesh L., Devi B.K.Y., Santana N., Rakesh N.: Oral and salivary changes among renal patients undergoing hemodialysis: A cross-sectional study. Indian J Nephrol. 2013; 23: 125-9.

15. Oyetola E.O., Owotade F.J., Agbelusi G.A., Fatusi O.A., Sanusi A.A.: Oral findings in chronic kidney disease: implications for management in developing countries. BMC Oral Health. 2015; 15, 24. https://doi.org/10.1186/s12903-015-0004-z

16. Sardari F., Hajisadeghi S., Tahmasbi A., Asayesh H., Eslami H.: Dental Health Status in Renal Dialysis Patients Compared to Healthy Individuals. JSSU. 2015; 23 (9): 844-2.

17. Kim Y.J., de Moura L.M., Caldas C.P., Perozini C., Ruivo G.F., Pallos D.: Evaluation of periodontal condition and risk in patients with chronic kidney disease on hemodialysis. Einstein. 2017;15(2):173-77.

18. Verma S., Frambach G.E., Seilstad K.H., Nuovo G., Porcu P., Magro C.M.: Epstein-Barr virus-associated B-cell lymphoma in the setting of iatrogenic immune dysregulation presenting initially in the skin. J Cutan Pathol. 2005; 32: 474-83.

19. Morawski K., Garnick J., El-Amm J.M., West M.S., Sillix D.H., Chandrasekar P.H., et al: Infectious complications after kidney transplantation: current epidemiology and associated risk factors. Clin Transplant. 2006; 20: 401-9.

20. Kanjevac T., Bijelic B., Brajkovic D., Vasovic M., Stolic R.: Impact of Chronic Kidney Disease Mineral and Bone Disorder on Jaw and Alveolar Bone Metabolism: A Narrative Review. Oral Health Prev Dent. 2018;16(1): 79-5.

21. Akar H., Akar G.C., Carrero J.J., Stenvinkel P., Lindholm B.: Systemic consequences of poor oral health in chronic kidney disease patients. CJASN. 2011; 6: 218-26.

22. Stolic R.: Most important chronic complications of arteriovenous fistulas for hemodialysis. Med Princ Pract. 2013; 22: 22028.

23. Ellis J.S.: New year challenges: major challenges facing today's leaders of dental education. Eur J Prosthodont Restor Dent. 2004; 12: 143.

24. Spolidorio L.C., Spolidorio D.M., Massucato E.M., Neppelenbroek K.H., Campanha N.H., Sanches M.H.: Oral health in renal transplant recipients administered cyclosporin A or tacrolimus. Oral Dis. 2006; 12: 309-4.

25. Radwan-Oczko M., Boratynska M., Zietek M., Zoledziewska M., Jonkisz A.: The relationship of transforming growth factorB1 gene polymorphism, its plasma level, and gingival overgrowth in renal transplant recipients receiving different immunosuppressive regimens. J Periodontol. 2006; 77: 865-3.

26. Costantinides F., Castronovo G., Vettori E., Frattini C., Artero M.L., Bevilacqua L., et al: Dental Care for Patients with EndStage Renal Disease and Undergoing Hemodialysis. International Journal of Dentistry Volume. 2018|Article ID 9610892|8 pages | https://doi.org/10.1155/2018/9610892. 
27. Kitamura M., Mochizuki Y., Miyata Y., Obata Y., Mitsunari K., Matsuo T., et al: Pathological Characteristics of Periodontal Disease in Patients with Chronic Kidney Disease and Kidney Transplantation. Int J Mol Sci. 2019; 20(14), 3413. https://doi.org/10.3390/ijms20143413.

28. Souza C.R., Libério S.A., Guerra R.N., Monteiro S., Silveira E.J., Pereira A.L.: Assessment of periodontal condition of kidney patients in hemodialysis. Rev Assoc Med Bras. 2005; 51: 285-9.

29. Yue H., Xin W., Cong-Xiao Z., Yu-Dan W., Li-Li J., Xiao-Yu Z., et al: Risk factors of periodontal disease in maintenance hemodialysis patients. Medicine. 2017; 96(35):7892. doi: 10.1097/MD.0000000000007892.

30. Demonstrator P.S.: Assessment of periodontal health of patients undergoing renal dialysis. IJADS. 2017; 3(4): $397-9$.

31. Davidovich E., Schwarz Z., Davidovitch M., Eidelman E., Bimstein E.: Oral findings and periodontal status in children, adolescents and young adults suffering from renal failure. J Clin Periodontol. 2005; 32: 1076-1082.

32. Olcay K., Eyuboglu T.F., Erkan E.: Cyclic fatigue resistance of waveone gold, protaper next and 2shape nickel titanium rotary instruments using a reliable method for measuring temperature. Niger J Clin Pract. 2019; 22: 1335-40.

33. Teshome A., Yitayeh A.: The effect of periodontal therapy on glycemic control and fasting plasma glucose level in type 2 diabetic patients: systematic review and meta-analysis. BMC Oral Health. 2017; 17, 31. https://doi.org/10.1186/s12903016-0249-1.

34. Buhlin K., Gustafsson A., Pockley A.G., Frostegård J., Klinge B.: Risk factors for cardiovascular disease in patients with periodontitis. Eur Heart J. 2003; 24: 2099-107.

35. Stolić R., Trajković G., Jovanović A., Stolić D., Perić V., Sovtić S., et al: Carotid ultrasonographic parameters as markers of atherogenesis and mortality rate in patients on hemodialysis. Vojnosanit Pregl. 2010; 67: $916-22$

36. Slade G.D., Ghezzi E.M., Heiss G., Beck J.D., Riche E., Offenbacher S.: Relationship between periodontal disease and Creactive protein among adults in the Atherosclerosis Risk in Communities study. Arch Intern Med. 2003; 163: 1172-79.

37. Stolic R.V., Trajkovic G.Z., Peric V.M., Stolic D.Z., Sovtic S.R., Aleksandar J.N., et al: Impact of metabolic syndrome and malnutrition on mortality in chronic hemodialysis patients. J Ren Nutr. 2010; 20(1): 38-3.

38. Stolic R.V., Trajkovic G.Z., Peric V.M., Jovanovic A.N., Markovic S.R., Sovtic S.R., et al: The influence of atherosclerosis and plasma D-dimer concentration in patients with a functioning arteriovenous fistula for maintenance hemodialysis. Int Urol Nephrol. 2008; 40(2): 503-8.

39. Loos B.G., Craandijk J., Hoek F.J., Wertheim-van Dillen P.M., van der Velden U.: Elevation of systemic markers related to cardiovascular diseases in the peripheral blood of periodontitis patients. J Periodontol. 2000; 71(10): 1528-34.

40. D'Aiuto F., Parkar M., Andreou G., Suvan J., Brett P.M., Ready D., et al: Periodontitis and systemic inflammation: control of the local infection is associated with a reduction in serum inflammatory markers. J Dent Res. 2004; 83: 156-60.

41. Bastos J.A., Diniz C.G., Bastos M.G., Vilela E.M., Silva V.L., Chaoubah A., et al: Identification of periodontal pathogens and severity of periodontitis in patients with and without chronic kidney disease. Arch Oral Biol. 2011; 56(8): 804-11.

42. Castillo D.M., Sánchez-Beltrán M.C., Castellanos J.E., Sanz I., Mayorga-Fayad I., Sanz M., et al: Detection of specific periodontal microorganisms from bacteraemia samples after periodontal therapy using molecular-based diagnostics. J Clin Periodontol. 2011; 38(5): 418-27.

43. Vilela E.M., Bastos J.A., Fernandes N., Ferreira A.P., Chaoubah A., Bastos M.G.: Treatment of chronic periodontitis decreases serum prohepcidin levels in patients with chronic kidney disease. Clinics (Sao Paulo). 2011; 66: 657-62.

44. Ardalan M.R., Ghabili K., Pourabbas R., Shoja M.M.: A causative link between periodontal disease and glomerulonephritis: a preliminary study. Ther Clin Risk Manag. 2011; 7: 93-8.

45. Brotto R.S., Vendramini R.C., Brunetti I.L., Marcantonio R.A., Ramos A.P., Pepato M.T.: Lack of correlation between periodontitis and renal dysfunction in systemically healthy patients. Eur J Dent. 2011; 5: 8-18.

46. Grubbs V., Plantinga L.C., Crews D.C., Bibbins-Domingo K., Saran R., Heung M., et al: Centers for Disease Control and Prevention CKD Surveillance Team: Vulnerable populations and the association between periodontal and chronic kidney disease. Clin J Am Soc Nephrol. 2011; 6: 711-17.

47. Iwasaki Y., Otsuka H., Yanagisawa N., Hisamitsu H., Manabe A., Nonaka N., et al: In situ proliferation and differentiation of macrophages in dental pulp. Cell Tissue Res. 2011; 346: 99-109.

48. Parkar S.M., Ajithkrishnan C.G.: Periodontal status in patients undergoing hemodialysis. Indian J Nephrol. 2012; 22: 246-50. 